${ }^{1}$ Neurological Department, Klinik Landstrasse, Messerli Institute, Vienna, Austria ${ }^{\mathrm{a}} \mathrm{MD}, \mathrm{PhD}$.

There are no conflicts of interest. No funding was received.

Author contribution: JF: design, literature search, discussion, first draft, critical comments

Recibido el 24 de junio de 2020 aceptado el 21 de octubre de

Corresponding author: Finsterer J, MD, PhD Postfach 20 1180 Vienna Austria, Europe. fifigs1@yahoo.de

\section{Trametinib and dabrafenib induced rhabdomyolysis, renal failure, and visual loss. Report of one case}

\author{
JOSEF FINSTERER ${ }^{1, \mathrm{a}}$
}

\begin{abstract}
MEK- and BRAF-inhibitors trametinib and dabrafenib are successfully used for BRAF-mutated, metastasizing melanoma, but these compounds may induce side effects. We report a 50 years old female with BRAF-mutated metastasizing melanoma who received trametinib $(2 \mathrm{mg} / \mathrm{d})$ and dabrafenib (200 $\mathrm{mg} / \mathrm{d})$ after using interferon without benefit. Shortly after starting trametinib/dabrafenib, she experienced an inability to abduct the left eye. Eight days after starting this therapy the patient experienced loss of appetite, vomiting, diarrhea, vertigo, and fever of $40^{\circ} \mathrm{C}$. Two days later she experienced visual loss, requiring permanent support for her daily activities. Two further days later myoglobinuria appeared in the absence of myalgias or muscle weakness but accompanied by marked tiredness and inactivity. She could not eat or drink during four days prior to admission. The patient suspected an adverse effect of trametinib/dabrafenib and discontinued it 2 days prior to admission. Thereafter, she experienced an almost complete remission of the deficits except for ocular muscle weakness and visual impairment.
\end{abstract}

(Rev Med Chile 2020; 148: 1684-1689)

Key words: Drug-Related Side Effects and Adverse Reactions; Leukopenia; Rhabdomyolysis.

\section{Rabdomiolisis, falla renal y pérdida de visión inducidas por trametinib y dabrafenib. Informe de un caso}

Los inhibidores de MEX and BRAF como trametinib y dabrafenib se usan en el melanoma metastásico con mutación BRAF, pero pueden tener efectos secundarios. Informamos una paciente de 50 años con un melanoma metastásico con la mutación BRAF que recibió trametinib (2 mg/día) y dabrafenib (200 mg/ día) después de usar interferón sin beneficio. Después de iniciar esta terapia la paciente notó una incapacidad de abducir el ojo izquierdo. Ocho días después de iniciar el tratamiento, tuvo falta de apetito, vómitos, diarrea, vértigo y fiebre de $40^{\circ} \mathrm{C}$. Dos días después notó pérdida de su agudeza visual, requiriendo asistencia para efectuar sus actividades de vida diaria. Dos días después apareció coluria, en ausencia de mialgias o debilidad muscular, pero acompañadas de fatiga. Ella no pudo comer o tomar líquidos por cuatro días antes de ingresar al hospital. La paciente sospechó que estaba experimentando efectos secundarios de los medicamentos y los suspendió dos días antes del ingreso, experimentando una casi completa remisión de sus sintomas, con excepción de la debilidad de musculatura ocular y déficit visual.

Palabras clave: Efectos Colaterales y Reacciones Adversas Relacionados con Medicamentos; Leucopenia; Rabdomiólisis. 


\section{Introduction}

Trametinib is an inhibitor of protein kinase signaling pathways by inhibiting MAP-kinases (MEKs), (MEK-inhibitor). Dabrafenib is also a MAP-kinase inhibitor, which inhibits the function of BRAF (BRAF-inhibitor). Trametinib alone or together with dabrafenib is successfully applied for BRAF-mutated, metastasizing melanoma ${ }^{1}$. If trametinib is given alone, the tumor tends to be- come resistant to therapy with time by activating alternative signaling pathways. Consequently, combination strategies with drugs that block not only the primary mutated BRAF-kinase but also the alternative pathways implicated in the development of resistance (e.g. dabrafenib) represent a better strategy for improving survival in patients with tumors harboring BRAF mutations ${ }^{2}$. Despite their effectivity, MEK- and BRAF-inhibitors carry the risk of side effects (Table 1) 13,4 $^{3,4}$ as in the following case.

Table 1. Side of trametinib alone, dabrafenib alone, and of their combination

\begin{tabular}{|c|c|c|c|}
\hline Agent & Side effect & Reported & Index case \\
\hline Trametinib & $\begin{array}{l}\text { Rash } \\
\text { Diarrhoea } \\
\text { Edema } \\
\text { Fatigue } \\
\text { Retinopathy } \\
\text { Osteopenia } \\
\text { Reduced systolic function }\end{array}$ & $\begin{array}{l}{[1]} \\
{[1]} \\
{[1]} \\
{[1]} \\
{[6]} \\
{[7]} \\
{[8]}\end{array}$ & $\begin{array}{l}\text { No } \\
\text { Yes } \\
\text { No } \\
\text { Yes } \\
\text { Yes } \\
\text { No } \\
\text { Yes }\end{array}$ \\
\hline Dabrafenib & Pyrexia & [8] & Yes \\
\hline Ocular & $\begin{array}{l}\text { Uveitis } \\
\text { Visual field defects } \\
\text { Retinal detachment }\end{array}$ & $\begin{array}{r}{[9]} \\
{[10]} \\
{[11]}\end{array}$ & $\begin{array}{l}\text { No } \\
\text { Yes } \\
\text { No }\end{array}$ \\
\hline Cardiac & $\begin{array}{l}\text { Heart failure } \\
\text { Cardiac tamponade } \\
\text { Arterial hypertension } \\
\text { Heart failure } \\
\text { Granulomatous myocarditis }\end{array}$ & $\begin{array}{l}{[12]} \\
{[13]} \\
{[14]} \\
{[15]} \\
{[16]}\end{array}$ & $\begin{array}{c}\text { No } \\
\text { No } \\
\text { No } \\
\text { Yes (proBNP } \uparrow) \\
\text { No }\end{array}$ \\
\hline Dermatological & $\begin{array}{l}\text { Squamous cell carcinoma } \\
\text { Panniculitis } \\
\text { Vitiligo-like lesion } \\
\text { Xantho-granulomatous lesions } \\
\text { Erythema nodosum } \\
\text { Keratitis sicca } \\
\text { Histiocytoid sweets syndrome } \\
\text { Pyoderma gangraenosum } \\
\text { Localised hyperkeratosis } \\
\text { Verrucous keratosis } \\
\text { Keratoakanthoma }\end{array}$ & $\begin{array}{r}{[12]} \\
{[17]} \\
{[17]} \\
{[18]} \\
{[8]} \\
{[8]} \\
{[19]} \\
{[20]} \\
{[21]} \\
{[21]} \\
{[21]}\end{array}$ & $\begin{array}{l}\text { No } \\
\text { No } \\
\text { No } \\
\text { No } \\
\text { No } \\
\text { No } \\
\text { No } \\
\text { No } \\
\text { No } \\
\text { No } \\
\text { No }\end{array}$ \\
\hline Others & $\begin{array}{l}\text { Pyrexia } \\
\text { Nausea } \\
\text { Procalcitonin } \uparrow \text { (without infection) } \\
\text { Asthenia } \\
\text { Arthralgia } \\
\text { Liver hemorrhage }\end{array}$ & $\begin{array}{r}{[1]} \\
{[1]} \\
{[22]} \\
{[23]} \\
{[23]} \\
{[24]}\end{array}$ & $\begin{array}{l}\text { Yes } \\
\text { Yes } \\
\text { No } \\
\text { No } \\
\text { No } \\
\text { No }\end{array}$ \\
\hline
\end{tabular}




\section{Case report}

The patient was a 50 year-old Caucasian female. Her height was $178 \mathrm{~cm}$, and weight $79 \mathrm{~kg}$. She was referred for fever, acute visual loss, and rhabdomyolysis. Some years before she had undergone a resection for a right shoulder melanoma, and was postoperatively treated with interferon, which had to be discontinued because of side effects. Fourteen months later she had to undergo resection of the lymph nodes of the right axilla, of which one was infiltrated by the melanoma. Postoperatively, oral therapy with trametinib $(2 \mathrm{mg} / \mathrm{d})$ and dabrafenib $(200 \mathrm{mg} / \mathrm{d})$ was initiated. Shortly afterwards, inability to abduct the left bulb occurred. Eight days after starting this therapy, the patient experienced loss of appetite, vomiting, diarrhea, vertigo, and fever up to $40^{\circ} \mathrm{C}$. Two days later she recognized sudden visual loss, requiring permanent support for accomplishing her daily activities. Another two days later a relative reported she presented a cola-like urine accompanied by marked tiredness and inactivity without myalgias or muscle weakness. She could not eat or drink during for four days prior to admission.
Suspecting side effects of trametinib/dabrafenib, the patient discontinued trametinib/dabrafenib herself two days prior to admission. Additionally, her history was positive for arterial hypertension, sicca-syndrome, and surgery for strabismus at ages 26 and 44 years respectively. The family history was positive for diabetes (mother), hypertension (mother), and asthma (father). She was regularly taking acetyl-salicylic acid and amlodipine.

At admission, the C-reactive protein (CRP) was markedly increased (Table 2) and piperacillin/tazobactam was given. Additionally, she presented with anemia, severe thrombocytopenia, hyponatremia, severe renal insufficiency, and high plasma creatinkinase (CK) (Table 2). The proBNP value was $1933 \mathrm{ng} / \mathrm{L}$ (normal value $<169 \mathrm{ng} / \mathrm{L}$ ). There was severe vitamin-D deficiency and secondary hyperparathyroidism was also diagnosed. ANA-antibodies were positive, as well as antibodies against SS-A/Ro. Amylase and lipase values were elevated. There was marked proteinuria. Ophthalmologic investigations revealed visual impairment (right: 0.1 , left: 0.8 ) with visual field defects, which continuously resolved after discontinuation of trametinib/dabrafenib

Table 2. Blood chemical values during hospitalisation

\begin{tabular}{|llccccccc|}
\hline Parameter & RL & hd1 & hd2 & hd4 & hd5 & hd6 & hd8 & hd13 \\
CRP & $-5.0 \mathrm{mg} / \mathrm{L}$ & $\mathbf{2 0 4 . 9}$ & $\mathbf{2 3 4 . 4}$ & $\mathbf{8 0 . 1}$ & $\mathbf{5 2 . 4}$ & $\mathbf{3 2 . 6}$ & $\mathbf{1 . 5}$ & 3.0 \\
\hline Leucocytes & $3.9-10.2 \mathrm{G} / \mathrm{L}$ & 6.0 & 4.4 & 4.4 & $\mathbf{2 . 9}$ & $\mathbf{2 . 8}$ & $\mathbf{2 . 1}$ & $\mathbf{3 . 1}$ \\
\hline Erythrocytes & $3.9-5.2 \mathrm{~T} / \mathrm{L}$ & 4.67 & 4.18 & $\mathbf{3 . 8 0}$ & $\mathbf{3 . 4 3}$ & $\mathbf{3 . 3 1}$ & $\mathbf{3 . 0 3}$ & $\mathbf{3 . 2 2}$ \\
\hline Hemoglobin & $12-15.6 \mathrm{~g} / \mathrm{dl}$ & 13.9 & 12.5 & $\mathbf{1 1 . 1}$ & $\mathbf{1 0 . 1}$ & $\mathbf{1 0 . 0}$ & $\mathbf{8 . 9}$ & $\mathbf{9 . 5}$ \\
\hline Hematocrit & $35.5-45.5 \%$ & 37.4 & $\mathbf{3 4 . 1}$ & $\mathbf{3 1 . 4}$ & $\mathbf{2 8 . 8}$ & $\mathbf{2 8 . 0}$ & $\mathbf{2 5 . 4}$ & $\mathbf{2 8 . 5}$ \\
\hline Thrombocytes & $150-370 \mathrm{G} / \mathrm{L}$ & $\mathbf{4 8}$ & $\mathbf{5 1}$ & $\mathbf{4 8}$ & $\mathbf{5 3}$ & $\mathbf{7 1}$ & 151 & 347 \\
\hline Sodium & $136-145 \mathrm{mmol} / \mathrm{L}$ & $\mathbf{1 2 9}$ & 136 & 139 & 139 & 143 & 139 & 143 \\
\hline Potassium & $3.4-4.5 \mathrm{mmol} / \mathrm{L}$ & 3.7 & $\mathbf{3 . 3}$ & $\mathbf{3 . 7}$ & 3.4 & 3.4 & 3.7 & 3.8 \\
\hline Creatinine & $0.5-0.9 \mathrm{mg} / \mathrm{dl}$ & $\mathbf{3 . 4 8}$ & $\mathbf{4 . 5 8}$ & $\mathbf{5 . 1 0}$ & $\mathbf{4 . 1 6}$ & $\mathbf{2 . 8 2}$ & $\mathbf{1 . 3 9}$ & $\mathbf{0 . 9 1}$ \\
\hline GFR & $>60 \mathrm{~mL} / \mathrm{min} / 1.7 \mathrm{~m} \mathbf{m}^{2}$ & $\mathbf{1 5}$ & $\mathbf{1 0}$ & $\mathbf{9}$ & $\mathbf{1 2}$ & $\mathbf{1 9}$ & $\mathbf{4 4}$ & 71 \\
\hline Creatine-kinase & $-170 \mathrm{U} / \mathrm{L}$ & $\mathbf{1 1 8 7}$ & $\mathbf{2 2 1 8}$ & $\mathbf{9 7 7}$ & $\mathbf{5 3 3}$ & $\mathbf{2 9 7}$ & 142 & 46 \\
\hline GOT & $10-35 \mathrm{U} / \mathrm{L}$ & $\mathrm{nd}$ & $\mathbf{2 2 3}$ & $\mathrm{nd}$ & $\mathrm{nd}$ & $\mathbf{1 6 1}$ & $\mathbf{9 2}$ & $\mathbf{4 0}$ \\
\hline GPT & $10-35 \mathrm{U} / \mathrm{L}$ & $\mathbf{1 5 5}$ & $\mathbf{1 2 8}$ & $\mathrm{nd}$ & 27 & $\mathbf{3 7}$ & $\mathbf{3 6}$ & $\mathbf{4 6}$ \\
\hline Amylase & $28-100 \mathrm{U} / \mathrm{L}$ & $\mathbf{1 0 6}$ & 98 & 59 & 89 & $\mathbf{7 0}$ & $\mathbf{2 3 0}$ & $\mathbf{1 6 3}$ \\
\hline Lipase & $13-60 \mathrm{U} / \mathrm{L}$ & $\mathbf{8 0}$ & $\mathbf{7 7}$ & 35 & 39 & 58 & $\mathbf{1 3 9}$ & $\mathbf{1 2 3}$ \\
\hline
\end{tabular}

RL. Reference limits, hd: hospital day, CRP: C-reactive protein, GFR: glomerular filtration rate. GOT: glutamate-oxalate transaminase, GPT: glutamate pyruvate transaminase, nd: not done. 


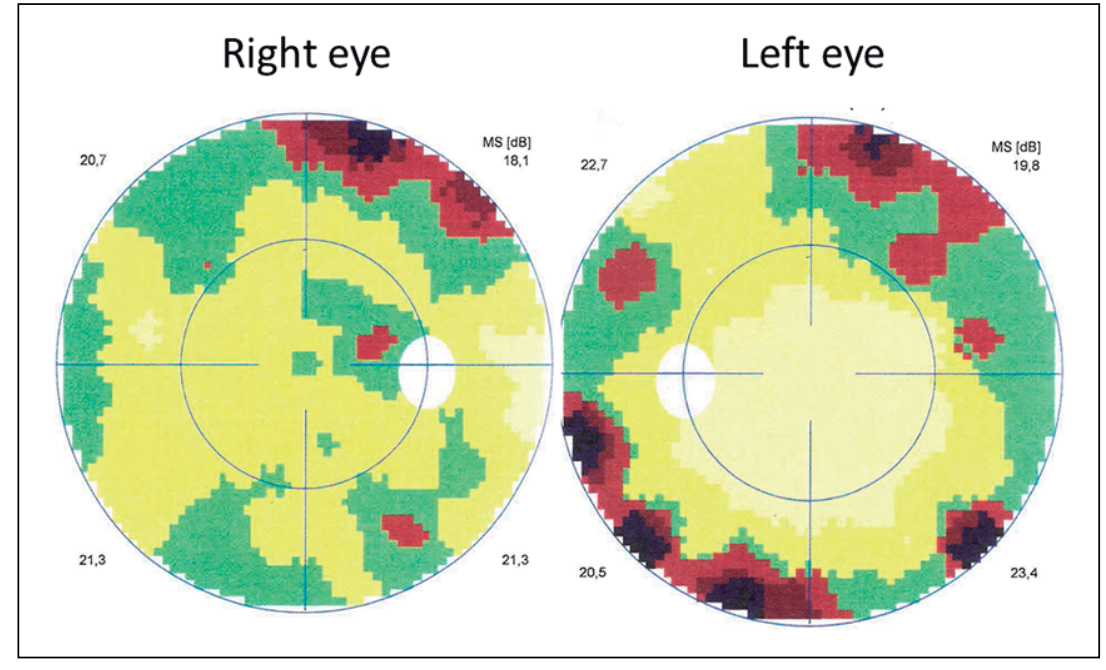

Figure 1. Visual field defects during remission of visual impairment 21d after admission. Visual fields were mot measured at the nadir of the visual impairment
(Figure 1). Upon symptomatic treatment, her condition steadily improved and most of the abnormal blood chemical values normalized. A few days after admission, the patient developed dysphagia being attributed to an oropharyngeal infection by candida albicans. Visually-evoked potentials were normal on the left side but revealed a reduced N70/P100 amplitude on the right side, being interpreted as either retinal or axonal lesion. Most of the side effects resolved within 3 weeks after discontinuing trametinib/dabrafenib, but some retinal lesions and the abduction deficit persisted (Figure 1).

\section{Discussion}

The presented patient is interesting for the combination of impaired bulb motility, diarrhea, vomiting, fever with elevated CRP, vertigo, visual impairment due to retinopathy, fatigue, renal insufficiency, and rhabdomyolysis, being attributed to treatment with trametinib/dabrafenib for BRAF-mutated, metastasizing melanoma. Side effects of trametinib alone, dabrafenib alone, or the combination of trametinib/dabrafenib are well recognized (Table 1$)^{5}$. Diarrhea, vomiting, fever, vertigo, retinopathy, renal failure, fatigue, and rhabdomyolysis have been previously reported as side effects of trametinib/dabrafenib (Table 1) 1,7-23, but the combination of these side effects occu- rring in the same patient is unusual. Particularly, the combination of weakness of an extra-ocular muscle, retinopathy, renal failure, and rhabdomyolysis has not been previously reported. The initial complication was impaired bulb motility to the left. Eight days after starting the compounds, diarrhea, vomiting, vertigo and fever developed, being attributed to a viral gastro-intestinal infection due to immunosuppression. Pyrexia was followed by severe visual impairment and later by asymptomatic rhabdomyolysis with a maximal CK-value of $2118 \mathrm{U} / \mathrm{L}$ (Table 2).

Explaining the presented side effects is challenging but the analysis of MEK and BRAF functions may partially elucidate the occurrence of these adverse reactions. MEK-inhibitors function as protein-kinase inhibitors of the MAP-kinases MEK1 (MAP2K1) and MEK2 (MAP2K2). MEK1 and MEK2 are part of the Ras/Raf/MAPK signaling pathway, which activate themselves by phosphorylation und thereby control of the cell cycle. MAP-kinases inhibit not only the tyrosine-kinase but also the serine-kinases. In case $B R A F$ is mutated, uncontrolled cell proliferation ensues. MEK inhibitors bind to MEK1 and MEK2 and inhibit the phosphorylation of transcription factors and thus proliferation of tumor cells. Since not only a single but several transcription factors are inhibited, it is conceivable that proteins other than those of the Ras/Raf/MAPK signaling pathway are inhibited. Whether diminished bulb motility 
under trametinib/dabrafenib was associated with previous surgery for strabismus remains speculative. In the same line, the high proBNP value could have been due to some kind of myocardial dysfunction, but this remains speculative as no echocardiography was carried out. Extra-ocular muscle weakness and rhabdomyolysis could be attributable to an underlying subclinical or mildly manifesting myopathy. Hemorrhage (liver, pericardium), previously reported as a side effect of trametinib/dabrafenib, can be attributed to thrombocytopenia as described in the present case.

Our report has several limitations. The patient was not immediately investigated after the onset of the symptoms, and no systematic search for systemic side effects of trametinib/dabrafenib was carried out.

This case shows that the combination of trametinib/dabrafenib for treating BRAF-mutated metastasizing melanoma may lead to severe side effects. The combination of diarrhea, vomiting, pyrexia, vertigo, retinopathy, renal failure, fatigue, and rhabdomyolysis is unique. The symptoms may largely resolve upon discontinuation of the drugs plus supportive therapy.

\section{References}

1. Hoffner B, Benchich K. Trametinib: A Targeted Therapy in Metastatic Melanoma. J Adv Pract Oncol 2018; 9: 741-5.

2. Morris V, Kopetz S. BRAF inhibitors in clinical oncology. F1000Prime Rep 2013; 5: 11. doi: 10.12703/ P5-11.

3. Irimada M, Fujimura T, Kambayashi Y, Tsukada A, Takahashi T, Hashimoto A, et al. Severe rhabdomyolysis developing in an advanced melanoma patient treated by pembrolizumab followed by dabrafenib trametinib combined therapy. J Dermatol 2019; 46: e256-8.

4. Muto Y, Ng W, Namikawa K, Takahashi A, Tsutsumida A, Nishida M, et al. Success of rechallenging dabrafenib and trametinib combination therapy after trametinib-induced rhabdomyolysis: a case report. Melanoma Res 2018; 28: 151-4.

5. Heinzerling L, Eigentler TK, Fluck M, Hassel JC, Heller-Schenck D, Leipe J, et al. Tolerability of BRAF/ MEK inhibitor combinations: adverse event evaluation and management. ESMO Open 2019; 4: e000491. doi: 10.1136/esmoopen-2019-000491.
6. Tyagi P, Santiago C. New features in MEK retinopathy. BMC Ophthalmol 2018; 18 (suppl 1): 221. doi: 10.1186/ s12886-018-0861-8.

7. Dumas M, Laly P, Gottlieb J, Vercellino L, Paycha F, Bagot $\mathrm{M}$, et al. Osteopenia and fractures associated with long-term therapy with MEK inhibitors. Melanoma Res 2018; 28: 641-4.

8. Davies MA, Saiag P, Robert C, Grob JJ, Flaherty KT, Arance A, et al. Dabrafenib plus trametinib in patients with BRAF(V600)-mutant melanoma brain metastases (COMBI-MB): a multicentre, multicohort, open-label, phase 2 trial. Lancet Oncol 2017; 18: 863-73.

9. Ben-Betzalel G, Baruch EN, Boursi B, Steinberg-Silman Y, Asher N, Shapira-Frommer R, Schachter J, Markel G. Possible immune adverse events as predictors of durable response to BRAF inhibitors in patients with BRAFV600-mutant metastatic melanoma. Eur J Cancer 2018; 101: 229-35.

10. Siedlecki J, Mackert M, Wolf A, Berking C, Priglinger SG, Eibl-Lindner K. Bilateral visual field defects in a patient treated with the MEK and BRAF inhibitors trametinib and dabrafenib for melanoma of unknown origin. Retin Cases Brief Rep 2019; 13: 215-9.

11. Rueda-Rueda T, Sánchez-Vicente JL, Moruno-Rodríguez A, Molina-Socola FE, Martínez-Borrego AC, López-Herrero F. Uveitis and serous retinal detachment secondary to systemic dabrafenib and trametinib. Arch Soc Esp Oftalmol 2018; 93: 458-62.

12. Broman KK, Dossett LA, Sun J, Eroglu Z, Zager JS. Update on BRAF and MEK inhibition for treatment of melanoma in metastatic, unresectable, and adjuvant settings. Expert Opin Drug Saf 2019; 18: 381-92.

13. Sundaram VR, Abbas T. Cardiac tamponade induced by dabrafenib and trametinib combination therapy for melanoma: Case report. Medicine (Baltimore) 2018; 97: e12751. doi: 10.1097/MD.0000000000012751.

14. Planchard D, Smit EF, Groen HJM, Mazieres J, Besse B, Helland $\AA$, et al. Dabrafenib plus trametinib in patients with previously untreated BRAF(V600E)-mutant metastatic non-small-cell lung cancer: an open-label, phase 2 trial. Lancet Oncol 2017; 18: 1307-16.

15. Banks M, Crowell K, Proctor A, Jensen BC. Cardiovascular Effects of the MEK Inhibitor, Trametinib: A Case Report, Literature Review, and Consideration of Mechanism. Cardiovasc Toxicol 2017; 17: 487-93.

16. Winkler JK, Buder-Bakhaya K, Ellert E, Herpel E, Martens UM, Enk A, et al. Acute heart failure as a result of granulomatous myocarditis: case report on a patient with metastatic melanoma treated with dabrafenib and trametinib. J Eur Acad Dermatol Venereol 2018; 32: e31-2. 
17. Consoli F, Manganoni AM, Grisanti S, Petrelli F, Venturini M, Rangoni G, et al. Panniculitis and vitiligo occurring during BRAF and MEK inhibitors combination in advanced melanoma patients: Potential predictive role of treatment efficacy. PLoS One 2019; 14: e0214884. doi: 10.1371/journal.pone.0214884.

18. Min MS, Yao J, Chee N, Sapadin AN, Shim-Chang H. Xanthogranulomatous reaction to trametinib for metastatic malignant melanoma. Cutis 2018; 102: 283-6.

19. Morgado-Carrasco D, Moreno-Rivera N, Fustà-Novell X, García-Herrera A, Carrera C, Puig S. Histiocytoid Sweet's syndrome during combined therapy with BRAF and MEK inhibitors for metastatic melanoma. Melanoma Res 2018; 28: 256-7.

20. Saint-Jean M, Le Moigne M, Daguze J, Bossard C, Peuvrel L, Quéreux G, et al. Pyoderma Gangrenosum Under Dabrafenib and Trametinib for Metastatic Melanoma. Acta Derm Venereol 2018;98:530-531.

21. Russo I, Zorzetto L, Frigo AC, Chiarion Sileni V, Alaibac M. A comparative study of the cutaneous side effects between BRAF monotherapy and BRAF/MEK inhibitor combination therapy in patients with advanced melanoma: a single-centre experience. Eur J Dermatol 2017; 27: 482-6.

22. Clay TD, Bowyer SE. Dabrafenib and trametinib treatment-associated fevers in metastatic melanoma causing extreme elevation in procalcitonin in the absence of infection. Anticancer Drugs 2018; 29: 802-5.

23. Martín Algarra S, Soriano V, Fernández-Morales L, Berciano-Guerrero MÁ, Mujika K, Manzano JL, et al. Dabrafenib plus trametinib for compassionate use in metastatic melanoma: A STROBE-compliant retrospective observational postauthorization study. Medicine (Baltimore) 2017; 96: e9523. doi: 10.1097/ MD.0000000000009523.

24. Loyson T, Werbrouck E, Punie K, Bonne L, Vandecaveye V, Bechter O. Hemorrhage of liver and bone metastases as a result of rapid response to dual BRAF/ MEK inhibition in metastatic melanoma: a case report. Melanoma Res 2018; 28: 147-50. 